Acta Universitatis Nicolai Copernici • Pedagogika XXXVII/1/2019

Nauki Humanistyczno-Społeczne • Zeszyt 447

DOI: http://dx.doi.org/10.12775/AUNC_PED.2019.006

\title{
Maria Szczepska-Pustkowska
}

University of Gdańsk

ORCID 0000-0002-8307-6566

\section{EXISTENTIAL QUESTIONS - THE ABSENT DIMENSION of Polish Religious education}

\begin{abstract}
:
My understanding of the category of existential question is broadly similar to S.G. Hartman, assuming that everyday life is an indivisible whole even if school education artificially introduces its division. Existential questions concern the fundamental conditions of human life and existence as such. They reach God, the beginnings of man and the world, the meaning and purpose of human life, the fragility of being, passing away, death or the existence of moral evil and good, etc. Along with questions about existence, man enters the very heart of all philosophical questions and the efforts undertaken to this end will last a lifetime and also concern the youngest in society. The purpose of this text is to reflect on the place and the role of existential questions in (Polish) religious education.
\end{abstract}

Ke y w o r d s: existential questions, religious education

\section{STRESZCZENIE:}

Kategorię pytanie egzystencjalne rozumiem za S.G. Hartmanem szeroko, wychodząc z założenia, że codzienne życie stanowi niepodzielną całość, nawet 
jeśli edukacja szkolna sztucznie wprowadza jej podział. Pytania egzystencjalne dotyczą fundamentalnych warunków ludzkiego życia i egzystencji jako takich. Sięgają Boga, początków człowieka i świata, sensu i celu ludzkiego życia, kruchości bytu, przemijania, śmierci czy istnienia moralnego zła i dobra, itp. Wraz z pytaniami o egzystencję człowiek wkracza w samo sedno wszelkich pytań filozoficznych, a podejmowane w tym celu wysiłki mają charakter procesu całożyciowego i dotyczą również najmłodszych. Celem niniejszego tekstu jest namysł nad miejscem i rolą pytań egzystencjalnych w (polskiej) edukacji religijnej.

Słowa klucze: pytania egzystencjalne, edukacja religijna

The discussion about religious education in public schools that has been ongoing in Europe for over three centuries covers both teaching content as well as methodology. Moreover, although it seems that religious education has found its place in school, the constant debate around it means that in the face of an advancing pluralism, challenges of multiculturalism and multi-religiosity, its status, mission, goals and tasks need to be constantly redefined. An important place in this debate is occupied by the issue of existential questions, which in many countries have become the basis for thinking about the content of religious education as well as its methodological "workshop". The aim of this text is to reflect on existential questions which the author perceives to be absent in the case of (Polish) religious education. To underline this absence, the issues analysed in this paper will be presented against a broader European background (with reference to Sweden).

\section{Religious education - a European outline}

The shape of religious education (legal conditions, goals, tasks, contents, pedagogical and theological concepts, etc.) differs significantly between countries. Its complex status in European school systems is ordered by classifications advocated by researchers such as F. Pajer, J. Charytański and R. Sauer. The first proposes that religious education should be distinguished as a compulsory, optional or extracurricular/ 
extramural ${ }^{1}$ subject; the second one differentiates religious education into confessional and non-confessional, as well as an extracurricular ${ }^{2}$ an extracurricular subject. And the third considers both the nature of religious education as a confessional/non-confessional subject and its status as a compulsory, optional or extramural ${ }^{3}$ subject.

The above picture is complemented by other criteria, such as:

- the entity that organises and supervises religious education (e.g. the state, school, Church/religious community, family, etc.);

- the recipients of religious education (only the so-called "believing" students who want to deepen their knowledge and religious faith, as well as the so-called "indifferent" students, seekers who are sometimes hostile towards classes);

- alternative classes (optional/compulsory classes offered in exchange for religion classes);

- the weekly number of hours of religion classes for subsequent levels of education 4 .

Another important and vividly discussed topic is the role and specific status of a religious education teacher, as well as different expectations towards him/her. Under the employment of public education, the teacher is a "state official" yet also remains under the direct influence, control and evaluation of religious institutions that delegate him/her to do the job. Therefore, such a teacher is usually subjected to strong pressure and assessment originating from various environments.

In most European countries, apart from France (with the exception of Alsace and Lorraine), Belarus, Bulgaria and Russia, religious education teaching takes place within the public education system, although

${ }^{1}$ F. Pajer, Nauczanie religii $w$ europejskich systemach oświatowych, "Przegląd Powszechny", no. 6 (1992), p. 393.

2 J. Charytański, Lekcje religii w Europie, "Ateneum Kapłańskie”, no. 498 (1992), p. 196.

3 R. Sauer, Religionsunterricht in Europa [Religious education in Europe]. In: Ökumenisches Arbeitsbuch Religionspädagogik, ed. H. Noormann, U. Becker, B. Trocholepczy, Stuttgart 2000, pp. 292-295.

4 R. Sauer, Religionsunterricht in..., op. cit. pp. 292-295; R. Chałupniak, Między katechezq a religioznawstwem. Nauczanie religii katolickiej $w$ szkole publicznej w Niemczech $w$ latach 1945-2000, Opole 2005, p. 35. 
the status of these lessons varies. Religion is a compulsory subject, regardless of whether a country recognises one of the denominations as a state religion (e.g. Great Britain, Denmark, Finland, Norway, Greece) or not (e.g. Germany, Belgium, Netherlands, Austria, Ireland, Cyprus, Romania).

Table 1.

Religious education in various European countries

\begin{tabular}{|c|c|c|}
\hline $\begin{array}{c}\text { Nature } \\
\text { of the subject } \\
\text { Status of the Subject }\end{array}$ & Denominational & $\begin{array}{c}\text { Non-denominational } \\
\text { (or over-denominational) }\end{array}$ \\
\hline Compulsory subject & $\begin{aligned}- & \text { Austria } \\
- & \text { Cyprus (Orthodox) } \\
- & \text { Denmark (from I-IX grades) } \\
& \text { (Evangelical-Lutheran) } \\
- & \text { Finland (Evangelical-Luthe- } \\
& \text { ran and Orthodox) } \\
- & \text { Greece (Orthodox) } \\
- & \text { Malta (Catholic) } \\
- & \text { Germany (except Bremen, } \\
& \text { Berlin, Brandenburg) } \\
- & \text { Norway (Evangelical-Luthe- } \\
& \text { ran) } \\
- & \text { Hungary (in confessional } \\
& \text { schools) } \\
- & \text { Italy (only in South Tyrol) }\end{aligned}$ & $\begin{array}{l}\text { - Denmark (X-XII grades) } \\
\text { - } \text { the Netherlands (although } \\
\text { there is no religious educa- } \\
\text { tion in public school, there } \\
\text { is a subject called "Spiritual } \\
\text { dimensions in education") } \\
-\quad \text { Sweden (7-16 years old) } \\
-\quad \text { Great Britain (from a Chri- } \\
\text { stian perspective) (up to } \\
16 \text { years old) }\end{array}$ \\
\hline Optional subject & $\begin{aligned} \text { - } & \text { Belgium } \\
\text { - } & \text { Bulgaria } \\
- & \text { Croatia } \\
\text { - } & \text { Czech Republic } \\
\text { - } & \text { Estonia } \\
- & \text { Spain } \\
- & \text { Netherlands (most private } \\
& \text { schools) } \\
- & \text { Ireland } \\
- & \text { Lithuania } \\
- & \text { Luxembourg (Catholic) } \\
- & \text { Latvia }\end{aligned}$ & $\begin{array}{l}\text { - Ireland (for older classes - } \\
\text { over-denominational) }\end{array}$ \\
\hline
\end{tabular}


Table 1. cd.

\begin{tabular}{lll}
\hline $\begin{array}{c}\text { Nature } \\
\text { of the subject } \\
\text { Status of the Subject }\end{array}$ & \multicolumn{1}{c}{ Denominational } & $\begin{array}{c}\text { Non-denominational } \\
\text { (or over-denominational) }\end{array}$ \\
\hline & - Germany (depending on the \\
& state) \\
& - Poland (Catholic) \\
& - Portugal (Catholic) \\
& - Romania \\
& - Slovakia \\
& - Hungary (public schools) \\
& - Italy \\
\hline Only out-of-school & - France \\
subject & - Slovenia \\
\hline
\end{tabular}

Based on: R. Sauer, Religionsunterricht in Europa. In: Ökumenisches Arbeitsbuch Religionspädagogik, red. H. Noormann, U. Becker, B. Trocholepczy, Stuttgart 2000, pp. 292-295.

The rule of "optionality" means that teaching religion occurs in individual education systems as an optional subject (complementary to ethics or other subjects focused on shaping knowledge about religion, values and norms or beliefs). Such a system is present, among others, in Italy, Spain, Portugal, Sweden, almost all of Switzerland, as well as in most of the so-called "post-communist countries"5.

${ }^{5}$ P. Mąkosa, Współczesne ujęcia nauczania religii $w$ europejskim szkolnictwie publicznym, "Roczniki pastoralno-katechetyczne", vol. 3, no. 58 (2011), pp. 123-136; R. Sauer, Religionsunterricht..., op. cit., pp. 292-295. 
Table 2.

Complementary subjects to religious education

\begin{tabular}{|c|c|c|c|}
\hline & Country & $\begin{array}{c}\text { Name of the subject } \\
\text { (together with a compulsory } \\
\text { number of hours) }\end{array}$ & $\begin{array}{l}\text { Suggested comple- } \\
\text { mentary lessons }\end{array}$ \\
\hline- & Belgium & Catechesis ( 2 or 3$)$ & Ethics \\
\hline- & Estonia & Religious education (1) & Ethics \\
\hline- & Finland & Religious education (1-2) & Humanistic ethics \\
\hline \multirow[t]{2}{*}{-} & France & Religious education (1-2) & Ethics \\
\hline & (Alsace and Lorraine) & Religious and moral education (1-2) & Ethics \\
\hline- & Spain & Religious education (1) & Ethics \\
\hline- & Lithuania & Religious teaching (1-3) & Ethics (in high school) \\
\hline- & Luxembourg & Religious education (1) & Ethics \\
\hline- & Latvia & $\begin{array}{l}\text { Religious education, life shaping, ethics, } \\
\text { study of religion (2) }\end{array}$ & $\begin{array}{l}\text { Ethics, values and } \\
\text { norms, philosophising }\end{array}$ \\
\hline- & Germany & $\begin{array}{l}\text { Christian knowledge and religious and } \\
\text { ethical education ( } 2 \text { ) }\end{array}$ & with children \\
\hline- & Norway & Religion classes (school catechesis) (2) & \\
\hline- & Poland & Moral and religious education (1) & \\
\hline- & Portugal & Religious education (1-2) & \\
\hline- & Slovakia & Religious education (2) & \\
\hline- & Hungary & (Catholic) Religion classes/ Religious & Worldview education \\
\hline \multirow[t]{6}{*}{-} & Austria, Bulgaria, & education/ Moral and religious-confes- & Ethics \\
\hline & Croatia, Cyprus, & sional education/ Catechesis & Personal and social \\
\hline & Czech Republic, & & development \\
\hline & Denmark, Greece, & & Ethics \\
\hline & $\begin{array}{l}\text { Netherlands, Ireland, } \\
\text { Malta, Romania, Slo- } \\
\text { venia, Sweden, Great }\end{array}$ & & $\begin{array}{l}\text { Ethics or history } \\
\text { of religion }\end{array}$ \\
\hline & Britain & & $\begin{array}{l}\text { No complementary } \\
\text { lessons }\end{array}$ \\
\hline
\end{tabular}

Based on: R. Sauer, Religionsunterricht in Europa. In: Ökumenisches Arbeitsbuch Religionspädagogik, edited by H. Noormann, U. Becker, B. Trocholepczy, Stuttgart 2000, pp. 292-295.

In Polish schools, religious education is a confessional subject which is optional and voluntary, meaning that parents and students (once they are over 18) can choose between religion and ethics (or none of these subjects). The problem, however, is that ethics is only present in 
a few Polish schools. In practice, therefore, it is not possible to implement this alternative. The landscape of religious education in the various European countries presented above allows for a broader knowledge in this area, which allows us to keep our distance from native solutions.

\section{Religious education - an outline of selected positions}

An interesting image of religious education emerges when we make different visions of religion the centre of reflection - as part of the culture or as an independent entity. This enables two positions to be distinguished that allow for different perceptions (and interpretations) of religious education. The first proposes its contextual understanding, while the second facilitates essential understanding ${ }^{6}$.

A group of researchers (such as R. Jackson ${ }^{7}$ and J. Ipgrave ${ }^{8}$, G. Skeie ${ }^{9}$ and H. Leganger-Krogstad ${ }^{10}$, or W. Weisse ${ }^{11}$ ) have emphasised how important it is for students to study religion in its full cultural context. On the other hand, however, they notice that personal knowledge and experience play an equally important role in this respect.

The essential understanding is represented by A. Wright, who argues that the contextual understanding of religious education, as ad-

6 G.G. Gunnarsson, Is a 'life question approach' appropriate when religious education has become a part of social studies? In: Challenging life existential questions as a resource for education, ed. J. Ristiniemi, G. Skeie, K. Sporre, Münster-New York 2018, p. 70.

7 R. Jackson, Contextual religious education and the interpretive approach. "British Journal of Religious Education", no. 92 (2008).

8 J. Ipgrave, Dialogue, citizenship and religious education. In: International perspectives on citizenship, education and religious diversity, ed. R. Jackson, London 2003.

9 G. Skeie, A culturally conscious religious education, Trondheim 1998.

${ }^{10} \mathrm{H}$. Leganger-Krogstad, Dialogue among young citizens in a pluralistic religious education classroom. In: International perspectives on citizenship, education and religious diversity, op. cit.

11 W. Weisse, Difference without discrimination: Religious education as a field of learning for social understanding? in: International Perspectives on Citizenship, Education and Religious Diversity, op. cit. 
vocated by the above-mentioned researchers, tends towards a narrow anthropological interpretation that reduces religion to a cultural dimension only. The horizontal dimension of religion overshadows the vertical dimension, which concerns questions of transcendence and ultimate truth; these aspects are what Wright indicates as its essence and main purpose, which is why he perceives any study of religion that does not explore these areas (irrespective of possible conclusions) as reductive $^{12}$. He suggests that religion should be legitimised in the school curriculum by referring to its own inherent meaning, i.e. the ability to share the actual order of things. At the same time, he points out that religion conceived in essence is also contextual by nature because it functions within the imposed historical, cultural and intellectual frames ${ }^{13}$.

Wright believes that religious education should be transformational. This means that it should lead to the transformation of pupils' lives by freeing them from the narrow horizons of modernity and opening the possibility of a religious understanding (of themselves, other people and the world). The intention is to enable students to transfer knowledge, beliefs, values and attitudes, helping them to formulate well-reasoned positions regarding religious claims of truth and develop the ability to think, act and communicate, bearing in mind the diversity of religious truth claims characteristic of the present ${ }^{14}$.

Robert Jackson, however, criticises Wright's proposal due to its overly "intellectual" approach to religious education, as well as for the great weight he places upon rationalism and how he almost excludes children's feelings and their expression from religious education. Indeed, Jackson warns against the danger of presenting religious worldviews as closed belief systems and proposes a more flexible, personal model that allows the individuality and uniqueness of the student to be considered $^{15}$.

12 A. Wright, Contextual religious education and the actuality of religions. "British Journal of Religious Education", no. 30 (2008), pp. 3-12.

13 A. Wright, Religion, education and Post-modernity, London 2004, pp. 208-222.

14 Ibidem.

15 R. Jackson, Rethinking religious education and plurality: Issues in diversity and pedagogy, London 2004, pp. 87-108. 
Jackson also emphasises that one should recognise ("in" and "for" religious education) the internal diversity of religious traditions and their (often oppositional or even controversial) disputed (co)existence, as well as the complexity of cultural expression and change, based on a social and individual perspective. He cites the example of religious diversity that can be found among children from Christian families ${ }^{16}$.

If we assume that religious education includes an understanding of the worldviews of others, then it becomes necessary to include in its content all the issues related to the representation of religious material and its interpretations. In these circumstances, the primary goal of religious education is to help children and young people find their own position in the discussion, as well as acquire the competence to understand other religious traditions or other ways of living. It is stressed by Jackson that students' own experiences, thoughts, questions and emotions should be used directly in religious education. Since the interpretation requires the student to compare concepts and ideas he or she understands with new ones, the student's perspective becomes an important part of the educational process. As a result, the content of religious education consists not only of information obtained by the student from the teacher or from the textbook but also the child's preexisting knowledge and personal experience, as well as the interaction between the child and the teacher.

Jackson also addresses the teacher of religious education and says that he/she should possess the requisite skills to manage dialogic teaching; if the teacher has the right degree of sensitivity (towards the pupils' own positions), he or she can create a religious education in which real discussion becomes possible - a discussion which deals with the encountered diversity. This approach embraces the possibility that pupils would deepen their own views by studying other positions and related traditions. It also provides students with the opportunity to use critical and creative learning abilities; it essentially establishes a "training ground" on which they can test different ways of thinking and interpreting reality. In this way, students' own religious and cultural

16 Ibidem, pp. 87-108. 
experiences, reflections and interactions become part of religious education $^{17}$.

Also included in this perspective is the position present in European debate on religious education supported by human rights arguments. According to this viewpoint, secular views should be respected as much as religious views. If so, they should also become an immanent part of religious education ${ }^{18}$. The task of integrating religious and nonreligious worldviews within this system is the greatest challenge that schools and teachers are currently facing ${ }^{19}$.

An interesting proposition that is gaining increasing popularity in Europe is the idea of the so-called "interreligious teaching". The justifications for this solution are sought in the increasing ideological and religious pluralism and the need for peaceful coexistence between various religions and worldviews. For instance, situations in which members of different Christian denominations, Judaism, Islam or atheists attend the same class are becoming increasingly common. The solution to this complex situation is the offer of such religious education which can be addressed even to a group that is strongly diverse in religious terms; for example, in the Norwegian integrated model of religious education, the educational content consists of religious and secular worldviews as well as aspects of ethics and philosophy ${ }^{20}$.

The main goal of teaching religious education in this way is to develop and nurture dialogue between people of different denominations and religions, leading to tolerance and peaceful coexistence between those with different religious affiliations ${ }^{21}$. Herein, pluralism means value and a chance to search for answers together, enrich each other,

17 Ibidem.

18 O.M. Hovde Bråten, World views in Norwegian RE. In: Challenging life existential questions..., op. cit., p. 157.

19 R. Jackson, The development and dissemination of Council of Europe policy on education about religions and non-religious convictions, "Journal of Beliefs and Values", no. 2 (2014), p. 139.

20 P. Mąkosa, Współczesne ujęcia nauczania religii..., op. cit., p. 133.

21 C. Sterkens, Interreligious learning. The problem of interreligious dialogue in Primary Education, Leiden 2001, pp. 63-64. 
and become aware of one's own powers, weaknesses and deficiencies ${ }^{22}$. The intention behind interreligious teaching is to strengthen the students' awareness of religious affiliation, while the experience of pluralism supports children in terms of deepening and internalising their religious beliefs. The condition for the success of such extensive religious education is the mature religious identity of the students taking part. Only under this condition it is possible to learn about other religions and shape a real dialogue between them ${ }^{23}$, which is limited by the widespread participation of students in this type of education.

Although the cited positions represent different approaches to the theoretical basis for understanding and interpreting religion and religious education, they also emphasise the importance of recognising weight and using the students' own (religious and ideological) experiences. They indicate that religion, as a school subject, should be available to all children regardless of their religious affiliation or religious or secular views of life. It is also important for religious education to recognise pluralism as an essential quality inscribed into reality and to highlight the importance of openness and flexibility in dealing with this diversity. Many researchers have also outlined the significant contribution of childhood experiences, astonishments, and above all children's existential questions within this educational structure.

\section{3. (Students') existential questions"}

Existential questions, because of their nature and scope, are sometimes referred to as philosophical questions ${ }^{24}$. People formulate these questions due to the need to explain where they come from, where they are going, and what the purpose and meaning of their lives is. They doubt, reflect on themselves and their own fate, and their lives are accompa-

I elaborate on this issue in the book titled Od filozofii dzieciństwa do dziecięcej filozofii życia. Casus władzy (i demokracji, Cracow 2011, U.III, pp. 101-156.

22 Ibidem, p. 63.

23 P. Mąkosa, Wspótczesne ujęcia nauczania religii......, op. cit., p. 133.

24 M. Lipman, A.M. Sharp, F.S. Oscanyan, Filozofia $w$ szkole, Warsaw 1997, pp. 53-56; S.G. Hartman, Children's philosophy of life, Stockholm 1986, p. 20. 
nied by a desire to find and understand the meaning of their own existence and to deal with it ${ }^{25}$. Existential questions, therefore, concern the fundamental conditions of human life and existence; they reach God, faith, the beginnings of all things, human beings and the world, the meaning and purpose of human life, the fragility of existence, transience, death or the existence of moral evil, etc. Diversified in form, they are the evidence of human efforts to understand and interpret life, expressing the individual personal need to organise the results of experiencing one's surroundings and existence in the broadest sense, establish the value of one's own reasoning, etc.

Along with questions about existence, humanity goes to the heart of all philosophical questions and the efforts made to this end are a lifelong process and apply to children and young people ${ }^{26}$ as well. While people differ in the way of research, the degree of abstraction and the external reference framework, they also have a common starting point - people are born, live and die, which seems to define the scope of their basic existential questions.

Matthew Lipman notes that children's inquiries are also directed towards understanding and meaning. Both children and adults have an innate sense of lack, which the author perceives as an experience more disturbing and frightening than the usual sense of incomprehensibility: 'Not being able to discover the meaning of your life experience is more than not knowing what to believe. Children whose life experience is not filled with meaning are desperately seeking clues that would help change this situation'27. They do not remain passive in the face of this lack, but actively seek what their experience will fill with the desired sense. The questions they ask for this purpose are evidence of constant openness to revealing the unknown and incomprehensible. They search for answers in various ways, including through scientific and

25 Z. Marek, Edukacja religijna w poszukiwaniu odpowiedzi na egzystencjalne pytania człowieka [Religious education in the search for answers to existential human questions], "Paedagogia Christiana", no. 2 (2017), p. 11.

26 S.G. Hartman, Children's philosophy..., op. cit., pp. 20-21.

27 M. Lipman, A.M. Sharp, F.S. Oscanyan, Filozofia..., op. cit., pp. 53-56; S.G. Hartman, Children's philosophy..., op. cit., p. 30. 
symbolic explanations and - most importantly, according to Lipman through philosophical explanations. Many questions asked by children require philosophical answers because they touch on complex metaphysical, logical or ethical issues ${ }^{28}$.

Lipman is particularly intrigued by the philosophical way in which children struggle with reality. He writes that they are looking for a meaning that is neither literal (like scientific explanations) nor symbolic (like fairy tales). They are looking for a meaning that can be called a philosophical understanding'29. Furthermore, although the children do not yet have a fully formed frame of reference in which they are able to embed their life experiences and discoveries, they try to explain what will make them understand the things that remain unknown and incomprehensible. They ask about the circumstances and conditions that allow the unknown/incomprehensible to be explained, giving meaning to the context and frame of reference to which the intriguing and disturbing things belong. Therefore, motivated by a lack of knowledge, understanding and certainty, they confront the unknown; they ask, express doubts, demand explanations, and one of the areas which children's inquiries are focused on is religion and the various accompanying issues.

William and Elisabeth Stern, while observing the development of their own children, saw how quickly they asked questions about the origin of everything that exists - including the supranatural figure of God. They discovered that everything had to happen at some point, and God is no exception to this rule. Stern recognised God and universal and essential questions connected with him as one of children's favourite motives for philosophical explorations ${ }^{30}$. His observations seem to prove that even young children are familiar with religious inquiries, as exemplified by the intriguing question asked by four-year-old Antek: 'Mum, do you know that God is a light? Only that probably not the one in a lamp... more like one in a moon'.

\footnotetext{
28 M. Lipman, A.M. Sharp, F.S. Oscanyan, Filozofia..., op. cit., p. 55.

29 Ibidem, p. 53.

30 E. Stern, Kind, Krankheit und Tod, München 1957.
} 


\section{1 (Children's) existential questions in religious education - the Swedish case}

In order to indicate the possible place of children's existential questions in religious education, this article refers to a Swedish example in which these questions have not only become its important part but also form the basis for further reforms of religious education at all levels. In Sweden, their significant educational potential has long been recognised and an effort has been made to put it into practice. Focusing on the students' existential questions in subsequent studies became, on the one hand, a way to continue the secularisation of religious education within Swedish schools; on the other hand, it provided a way to implement the children's rights to religious, philosophical and personal development ${ }^{31}$. Therefore, the individual student, as well as children's feelings, experiences, existential questions and interpretations of life based on them, has been placed at the centre of thinking about religious education $^{32}$; however, it should be highlighted that in subsequent education-

31 S.G. Hartman, Children searching for a philosophy of life. In: Challenging life existential questions..., op. cit., p. 23 [Following the Author, I am presenting examples of Swedish religious education projects: "Teaching methods in RE" (1967); "Children and existential questions" (1974); "Development in children's environmental orientation and philosophy of life" (1978); "Children's living conditions and life interpretation" (1987); "Children's life interpretation in a comparative perspective" (1994); "Children's and youth's life interpretation and the basic values of the school" (1999)].

32 The research on this subject was conducted, among others, by: S.G. Hartman, S.G., \& S. Petterson, Livsfrågor och livsåskådning hos barn: några utgångspunkter för en analys av barns livsfrågor och livsåskådning samt en presentation av några delstudier inom området, Stockholm 1980; S. G. Hartman, Barns tankar om livet, Stockholm 1986; K. Eriksson, På spaning efter livets mening: om livsfrågor och livsåskådning hos äldre grundskoleelever i en undervisningsmiljö som befrämjar kunskapande, Lund 1999; S.G. Hartman, Livstolkning hos barn och unga. In: Livstolkning och värdegrund: att undervisa om religion, livsfrågor och etik, Linköping 2000; E. Birkedal, „Noen ganger tror jeg på Gud, men...?” En undersøkelse av gudstro og erfaring med religiøs praktis i tidlig ungdomsalder, Trondheim 2001; B. Falkevall, Livsfrågor och relegionskunskap. En belysning av ett centralt begrepp i svensk religionsdidaktik, Stockholm 2010. 
al programmes created from 1962 to the present day the main accents have changed.

In the early 1960s, the Swedish curriculum for religious education in public schools ${ }^{33}$ focused on the subject of "knowledge of Christianity", which emphasised the so-called "objectivity". This aroused many controversies among teachers because the contemporary curriculum did not clearly specify how the key requirements of objectivity should be understood. As a result, they were not sure how to approach religious education ${ }^{34}$.

Considering these doubts, the Teenager and Life Questions ${ }^{35}$ were conducted among teenagers in the late 1960s. Their results showed that young people were interested in many existential problems, especially the anthropological and social conditions of humanity. Among the most important specific problems identified by young people were race, sexuality, love, suffering, values and norms, freedom, responsibility, guilt and punishment, trust, loneliness and community, good and evil, etc. Although questions about God, faith and religion took quite a distant place in the questionnaire, at the same time the youth expressed their expectations of carrying out the right to discuss important questions during religion classes ${ }^{36}$, which was considered a significant argument for further reforms of religious education.

The analysis of the obtained research results led to the proposal to change the contemporary perspective of teaching religion and to shift the emphasis from objectivity to the students themselves. The new programme was built around the students' existential questions and life

${ }^{33}$ Lgr 62: Läroplan för grundskolan, Stockholm 1962; G.G. Gunnarsson, Is a 'life question approach' appropriate when religious education has become a part of social studies? In: Challenging life existential questions..., op. cit., p. 73.

34 S.G. Hartman, Hur religionsämnet formades. In: Livstolkning och värdegrund: att undervisa om religion, livsfrågor och etik, Linköping 2000, pp. 212-251.

35 Tonåringen och livsfrågorna: elevattityder och undervisningen i livsåskådning och etik på grundskolans högstadium: elevundersökningar och metodiska förslag av en arbetsgrupp inom skolöverstyrelsen, Stockholm 1969.

36 G.G. Gunnarsson, Is a 'life question approach' appropriate when religious education has become a part of social studies?. In: Challenging life existential questions..., op. cit., p. 73. 
philosophy. The name of the subject, which had previously appeared in the curriculum ${ }^{37}$ as "religious education", was changed to "life-question education", and the guiding concept of "life questions" (livsfrägor) was permanently introduced into the religion curriculum for public schools.

The results of subsequent cyclical studies with young people ${ }^{38}$, published in 1980, pointed to the continuing tendencies detected in earlier studies ${ }^{39}$, while parallel studies conducted among younger children revealed that for them existential questions are also an important element of reflection on the world. The obtained results led to the conclusion that rather than applying only to the youth, beliefs, doubts and rebellious thoughts/contestations are characteristic and occupy an equally important place in the thinking of younger students, proving the tension and dynamics that occur between life questions and life philosophy of people at any age ${ }^{40}$.

Under the influence of these studies, the new curriculum ${ }^{41}$ emphasised the problematics of life. It is worth mentioning that at the end of the $20^{\text {th }}$ century, less attention was devoted to teaching about life itself, replacing this approach with a new one - oriented on the interpretation of life ${ }^{42}$. The term "life questions" has been replaced with the term "faith and views on life problems", and the emphasis has been shifted to knowledge and reflection covering various religions and views on life. However, the child perspective mentioned above still forms the axis of Swedish religious education.

There are number of reasons why the focus was mainly on the students' perspective. One of them was the desire to increase children's in-

37 Lgr 69: Läroplan för grundskolan. 1, Allmän del, Stockholm 1969.

38 Tonåringen och livet: undersökning och diskussion kring tonåringen och livsfrågorna, ed. T. Hasselrot, L.O. Lernberg, Stockholm 1980.

${ }^{39}$ G.G. Gunnarsson, Is a 'life question approach' appropriate ..., op. cit., pp. 73-74.

${ }^{40}$ For example: U. Ekström, J. Odencrants, Livsfrågor och attityder hos barn i åldrarna 9-13 år, Stockholm 1980.

${ }^{41}$ Lgr 80: Läroplan för grundskolan, Stockholm 1980; G.G. Gunnarsson, Is a 'life question approach' appropriate..., op. cit., p. 74.

42 Lpo 94: Kursplaner för grundskolan, Stockholm 1994; G.G. Gunnarsson, Is a 'life question approach' appropriate..., op. cit., p. 74. 
terest in religion as a school subject and the temptation to attract more students to attend these lessons. A much more important argument in favour of adopting this solution, however, was the attempt to create conditions for working with students that would encourage reflections on and explanations of their own positions; this was seen as an opportunity to achieve one of the most important goals of religious education, namely to help children broaden their existential experiences and knowledge, expand their own reference framework, and encourage them to reflect on important issues of life and ethics ${ }^{43}$.

Progressive religious and ideological pluralism (connected with the reception of immigrants from all over the world by Sweden) somewhat forced the development of such an approach to religious education that offers students help in dealing with the issue of plurality and diversity. Hence, Swedish religious education proposals emphasise the importance of studying (and building reflections on) various religious, cultural and philosophical views, as well as recognising the rights of individuals to present different religious and secular views as well as different religious and non-religious attitudes at school based on a particular religion in the customs of one's family, or more broadly, the community of origin ${ }^{44}$.

It is worth noting that the development trajectory of the Swedish approach to religious education is an example of such solutions where, despite constant searching, the student and his/her existential questions have been placed at the centre since the end of the 1960s. The fundamental assumption that has been made as the basis for all changes indicates that students as people (regardless of age) can personally relate to the religion and the beliefs associated with it. A strong emphasis is therefore placed on the so-called "children's perspective" of asking "about", of perceiving and interpreting these issues, although at the same time one cannot forget the interrelationships between the content of religious traditions and the numerous contexts that fill that per-

43 G.G. Gunnarsson, Is a 'life question approach' appropriate..., op. cit., p. 74.

44 R. Jackson, Rethinking religious education..., op. cit., p. 165; G.G. Gunnarsson, Is a 'life question approach' appropriate..., op. cit., p. 74. 
spective, and finally the relationship with the traditions and customs "brought" by students to the school environment.

Efforts have been made to encourage children of all ages to reflect on various life issues, their identity (including religious identity) and ethical attitudes towards them. Attention has also been paid to creating conditions in which questions can be asked and a personal attitude towards life can be developed, as well as enabling children to understand their own and other people's ways of thinking. An important value here is how students deal with individual existential questions that concern both the individual's situation and the need and desire to understand others. At lower levels of education, students are expected to reflect on basic life issues; at higher levels, however, they will engage in a dialogue whose essence will be the description, comparison and analysis of different ways of living in different religions and with different beliefs ${ }^{45}$.

Therefore, the fundamental question about religious education in Sweden is not whether students' existential questions should be encouraged, but HOW teachers can work with students on these questions in religion classes ${ }^{46}$.

The presented picture of Swedish solutions in the field of religious education would not be complete if we were to ignore the flaws highlighted by their critics. On the one hand, one of the objections is that the solutions have an excessive level of political correctness; on the other hand, the most serious objection is that hegemonic secular ideology is often still dominant in school practice. The most important role is played by deriving from "objectivity" and "worldview". Religion then appears to be in opposition to these concepts, which causes students to fear disclosing their own positions on religious issues ${ }^{47}$. Thus, although

45 G.G. Gunnarsson, Is a 'life question approach' appropriate..., op. cit., p. 75.

46 The International Scientific Conference Existential questions in research and education (Människors livsfrågor i forskning och undervisning) focused on this issue, Sigtuna (Sweden), 27-29 October 2016.

47 K. Kittelmann Flensner, Religious education in contemporary pluralistic Sweden, Göteborg 2015; C. Holmqvist Lidh, Representera och bli representerad: Elever med religiös positionering talar om skolans religionskunskapsundervisning, Karlstad 2016. 
existential questions in Sweden are - according to assumptions - an integral part of religious education, critics of this system have proved the existence of a serious gap between assumptions and practice ${ }^{48}$. They also seem to prove how difficult it is to introduce existential questions in teaching practice, outlining the legal and educational challenges associated with combining religious education for all with respect for the personal beliefs of those involved.

\subsection{Existential questions in Polish religious education}

Teaching religion in the form of catechesis returned to Polish schools after a long break at the turn of the years 1990-1991. The current Core Curriculum of Catechesis of the Catholic Church ${ }^{49}$ in Poland contains strict indications that determine the specificity of religion taught by the Church and obliges us to follow the so-called "principle of dual fidelity", i.e. fidelity to God and fidelity to man. Hence, it emphasises both the person of Christ (in his historical dimension), the mystery of the resurrection (the centre of human and world life) and the mystery of the Church. It mentions the importance of students' needs and their perceptive capabilities and - significantly - also points to the importance of existential questions and human experiences which can only be updated in the context of dialogue. In these circumstances, it is necessary to consider the adequate conditions and possibilities for dialogue in school in general as well as dialogue with an emphasis on catechetical thought of Roman Catholicism, whose main premise is the transfer of the Revealed Truth.

48 S. Risenfors, Liberal Muslim, atheist Hindu and born-again Christian identifications in relation to religion among three upper secondary students with experiences connected to migration. In: Challenging life existential questions... op. cit., pp. 119-136.

49 Konferencja Episkopatu Polski [Episcopal Conference of Poland], Podstawa programowa katechezy Kościoła katolickiego w Polsce, Kraków 2010. 
School research over several years shows that it is in no way interested in developing or being dialogical in teaching ${ }^{50}$ nor nurturing children's manifestations of philosophical reflection on the world. This also proves that teachers - despite being aware of the importance of dialogicality, the critical and creative nature of education - still prefer an adialogic, transmissive, reproductive model of working with students whereby (the teacher's) monologue dominates, providing children with ready and unified meanings, which leads to reproduction of ready-made knowledge. This mythologisation of knowledge transfer is firmly "hooked" in the work style of Polish schools ${ }^{51}$, the main weakness of which is the extreme unification of the acceptable ways of thinking which limits the students' ability to contribute to knowledge. An in-depth analysis of school practice in terms of its ability to resign from the transfer of knowledge, which is recognised as the only correct method for creating conditions for its active construction by students, reveals the advantage of the so-called 'knowledge acquired by following in teacher's footsteps' over knowledge through 'searching for a trace ${ }^{52}$. It is evident that in the case of religion lessons this has additional meaning resulting from the confessional nature of the subject, whose task is to 'enrich and broaden the cognitive horizons of human being' while simultaneously introducing 'a new kind of cognition, called "a religious cognition"'53. Religious education means a teaching process based on religious sources which combine the revelation of God and human experience ${ }^{54}$. Religion classes are to serve and validate the so-called 'descending theology of the Revealed Truth'55, which

50 D. Klus-Stańska, Mitologia transmisji wiedzy, czyli o konieczności szukania alternatyw dla szkoły, która amputuje rozum, "Problemy Wczesnej Edukacji", no. 2 (2008); B. Śliwerski B., Czy możliwy jest w szkole dialog?, "Paedagogia Christiana", no. 1 (2010).

51 D. Klus-Stańska, Mitologia transmisji..., op. cit., pp. 35-45.

52 D. Klus-Stańska, Konstruowanie wiedzy w szkole, Olsztyn 2002, pp. 229$-236$.

53 Z. Marek, Edukacja religijna w poszukiwaniu odpowiedzi na egzystencjalne pytania człowieka, "Paedagogia Christiana", no. 2 (2017), pp. 20-21.

54 Ibidem, pp. 20-21.

55 T. Bartoś, Jan Paweł II. Analiza krytyczna, Warsaw 2008, pp. 76-77. 
means that they are primarily about the transfer of the basic truths of faith, not only in a true but above all in an obliging way.

Maintaining a dialogue in view of descending theology, which results in thinking in categories of "religious parameters", is extremely difficult ${ }^{56}$. Like the parameters of the final product in industrial production, they form the basis for assessing the compliance of the religious and moral condition of a student with the assumed ideal of upbringing. In the case of the concept of "true" doctrine, there is no place during classes for children's questions, doubts and in-depth consideration of them, even when the catechist is aware of the value of dialogue ${ }^{57}$. In these circumstances, the child remains "asked" (not "asking"), "experienced" (not "experiencing"), and "taught" (not "learning"). Being "before a child" is therefore a general principle that dominates not only religion lessons but the entire school process as the student acquires knowledge by following the teacher's "footsteps". In a school that is abnormally attached to the teacher's monologue and the vision of a child patiently participating in the transfer (knowledge), it is impossible to develop and cultivate in-depth (religious) reflection.

A new Core Curriculum of Catechesis of the Catholic Church ${ }^{58}$ in Poland, which (along with new textbooks) will be gradually implemented from September 2020 to September 2023, will not change the abovementioned situation and will not be open to dialogue. On the contrary, it is a document that contains a strict record of knowledge, skills and (socio-moral) competences that children should master in kindergarten and during the subsequent twelve years of education. What we find in this record has little to do with encouragement for critical discussion. Rather, we are dealing with a project of systematic, patient shaping of students' beliefs and attitudes that leads to the formation of "church identity" - followers of the Catholic religion with well-grounded views,

56 P. Mąkosa, Katecheza młodzieży gimnazjalnej w Polsce. Stan aktualny i perspektywy rozwoju, Lublin 2009.

57 M. Cackowska, P. Stańczyk, Katecheza szkolna - między demokracją a katechezą zstępująca, "Teraźniejszość - Człowiek - Edukacja”, no. 1 (2012), p. 20.

58 Konferencja Episkopatu Polski, Podstawa programowa katechezy Kościoła Katolickiego w Polsce, Częstochowa 2018. 
with characteristic obedience (towards the Church and its teachings), who are active supporters and defenders, who undertake apostolic actions, and who will have resistance to secular views ${ }^{59}$. The mission of such extensive religious education is to awaken a strong religious emotionality, to promote fervent religiosity, and to create personality by teaching students to combat their own sinful nature.

This core curriculum adopts a new educational division, which includes three stages of religious education, i.e. kindergarten, grades I-IV and V-VIII, and secondary school education.

Kindergarten is a time in which the youngest people are to be introduced to the relationship with a personal God and a time to build trust in him. The purpose of this stage of education is to familiarise children with 'the Person of Jesus Christ, to show Mary in the work of salvation, to show saints as friends of God' ${ }^{\prime 60}$. A five-year-old should understand that 'through baptism he or she becomes a child of God'61 and will see 'the gifts of love through creation and redemption'62. They are taught to "cling" to Christ emotionally, which is made possible by the catechist organisation and support of all activities in this direction. This stage of religious education is dominated by approval and positive feelings (towards God, the world, the child, etc.), and the key word here is "love". This means that the pre-schooler is to live by the commandment of love, love God, and at the same time learn to evaluate their own behaviour in the light of the commandment of love between God and others ${ }^{63}$.

Grades I-IV include a series of catechesis which aim to prepare children for First Communion, as well as the post-communion stage (during which the emphasis is put on implementing confession and communion into practice). The key word becomes "obedience". The basis indicates that a child aged 7-11 should be 'obedient to the inspirations of the Holy Spirit', 'show gratitude to Jesus', 'take care of life in the

\footnotetext{
59 Ibidem, p. 44.

60 Ibidem, p. 21.

61 Ibidem, p. 22.

62 Ibidem, p. 21.

63 Ibidem, p. 22.
} 
state of sanctifying grace', as well as 'try to live in an attitude of vigilant waiting for the second coming of Christ' ${ }^{\prime 64}$. A student at this age is also expected to express a desire for "conscious and profound union with the Eucharistic God", to trust in God and follow Him's5. These expectations are to be realised thanks to the child's strong bond with divine characters, the use of family associations ("Mary as Mother"), systematic zealous prayers, as well as the so-called "soaring acts" leading to union with Christ and expressing gratitude towards him ${ }^{66}$. The Core curriculum recommends that the child 'accept the truth that the fruit of prayer depends on God's will' and that the child 'should submit to that will in and through prayer ${ }^{267}$. In this perspective, the intensive participation of the student in the liturgy is extremely important. The curriculum also recommends checking whether the student can 'explain the sense of practicing the first Friday of the month' and 'prepare properly for each part of the mass', for the First Communion and for the postCommunion period (in which the child should confess and receive the sacrament of communion as often as possible). At this stage of religious education, the child is also expected to be able to understand that 'the Eucharist is the sacrifice of Christ and the Church', in which he or she can participate through catechesis ${ }^{68}$. The education stage presented here is perceived as an introduction to building a "church identity" (of which an indispensable element is living with the awareness of sin, regret for sins, concern for one's own salvation, conviction in the need for regular work on oneself, and the decision to change one's life $\left.{ }^{69}\right)^{70}$.

In grades V-VIII, religious education includes systematic, closer and more intense preparations for Confirmation which put mystagogy at

\footnotetext{
64 Ibidem, p. 33.

65 Ibidem, p. 38.

66 Ibidem, p. 33.

67 Ibidem, p. 39.

68 Ibidem, p. 36.

69 It is worth noting here that the catechesis practiced in Polish schools dramatically simplifies the multi-faceted reality of sin, which is presented to younger students without its theological, anthropological, personalistic and community

${ }^{70}$ Konferencja Episkopatu Polski, Podstawa..., op. cit., p. 36.
} dimensions. 
the centre of teaching (Christian initiation in the mystery - into the spiritual mysterious reality, including the relationship between the sacrament of Confirmation and the history of salvation, between the sacramental sign and the life of faith). In secondary school, however, the main educational activities are focused on upbringing into Christian adulthood, deepening the knowledge of the Bible and Tradition, shaping the church's identity and preparing students to take apostolic activities. This is why the apology of faith is strongly emphasised (students justify it first for their own sake and later also for missionary purposes - among others, to become its apostles). The curriculum also provides that shaping the Catholic personality of a secondary school student should be associated with an 'effort of self-education'71, which involves discovering the word of God, interiorising biblical texts and the teachings of the Church. These are perceived as a source of answers to all youthful dilemmas, doubts and existential questions ${ }^{72}$. Moral formation, which is an integral part of religious education, is focused on the 'awareness of one's own sinfulness' ${ }^{73}$ and indicates its sources inherent in various threats present in the world (such as 'materialist-consumerist attitudes' and 'threats of gender ideology', which violate the Catholic view on the 'sense of human sexuality' and the traditional division of roles; sexuality is perceived as the greatest of threats) ${ }^{74}$. The catechist also becomes responsible for sex education here, teaching an adolescent to 'shape his/her sexuality responsibly as a gift from God'75, 'to nurture the purity of heart' ${ }^{16}$ and to 'describe what purity and its value are before and in marriage'77.

In such a perspective, the acquisition of (religious) knowledge does not consider the searching or critical analysis and assessment of its values which takes place in attempts at (philosophical) questioning and

71 Ibidem, p. 109.

72 Ibidem, pp. 99-100.

73 Ibidem, p. 111.

74 Ibidem, p. 113.

75 Ibidem, p. 102.

76 Ibidem, p. 113.

77 Ibidem, p. 113. 
thinking. Students' activity is limited here to passive, thoughtless absorption of ready, unified, undisputed (because it is dogmatic) revealed content. What is referred here as a "discussion" usually consists of consolidating these dogmatic meanings provided by the catechist. Here, the process of learning is reduced to allowing the student to learn what to think (with the emphasis on teaching content) rather than how to think (emphasis on strategies and principles of constructing religious knowledge). This important deficit applies to many school subjects, but in the case of religious education it takes on a special meaning because it serves to validate the descending theology of the Revealed Truth.

In religion classes, students do not use their potential intellectual capabilities. Their open, reflective, interrogative attitude towards reality (including the religious one) is "suspended" by catechesis, as it is particularly unlawful and unnecessary. The child's personal cultural and religious experiences are not considered at all in his/her religious education. Therefore, the religious knowledge conveyed to students is separated from thinking and experience while remaining strongly dependent on the dogma of faith. Religious education defined in this way ends up killing rather than cultivating a child's curiosity, meaning the student is the subject of religious "processing".

Despite the theoretical assumptions and declarations, religious education understood in this way also does not consider the significance of the diversity of religious traditions and their complex (co)existence, or the accompanying complexity of expression and cultural changes resulting from the social and individual perspectives of the students. Pluralism, the purpose of which - in relation to the principle of dialogue - is to build, merge, unite communities, and build openness and flexibility in dealing with diversity and multiplicity, is criticised as a defect inherent in reality ${ }^{78}$. It is seen to be good as long as trivial issues are in-

78 Śnieżyński M., Zarys dydaktyki dialogu, Kraków 1998, p. 136. 
volved", yet becomes an undesirable "compromise" when "otherness" means any departure from fundamental values ${ }^{80}$.

The content passed on to students during religion classes was and - as is apparent from the new Core Curriculum - will continue to be subordinated to the descending theology of revealed truth, dogma, and unambiguity, and the resulting formula of classes does not provide for discussion in either religious or secular space. Catechesis lessons leave no room for any doubts, inquiries or existential questions for students (young or older). Children are convinced that God is not to be asked or discussed about, but to be believed in. Religious education in Poland, unfortunately, remains a space devoid of children's questions.

\section{References}

Bartoś T., Jan Pawet II. Analiza krytyczna, Warsaw: Wydawnictwo Sic, 2008. Birkedal E., "Noen ganger tror jeg på Gud, men...?" En undersøkelse av gudstro og erfaring med religiøs praktis i tidlig ungdomsalder, Trondheim 2001.

Cackowska M., Stańczyk P., Katecheza szkolna - między demokracja a katechezq zstępująca, "Teraźniejszość - Człowiek - Edukacja”, 1 (2012): 19-38.

Chałupniak R., Między katechezq a religioznawstwem. Nauczanie religii katolickiej $w$ szkole publicznej $w$ Niemczech $w$ latach 1945-2000, Opole: Redakcja Wydawnictw Wydziału Teologicznego Uniwersytetu Opolskiego, 2005.

Charytański J., Lekcje religii w Europie, "Ateneum Kapłańskie”, 498 (1992): 194-207.

Ekström U., Odencrants J., Livsfrågor och attityder hos barn i åldrarna 9-13 år, Stockholm 1980.

Eriksson K., På spaning efter livets mening: om livsfrågor och livsåskådning hos äldre grundskoleelever i en undervisningsmiljö som befrämjar kunskapande, Lund 1999.

79 Specifically understood pluralism was recognised only in relation to the choice of textbooks, which is justified by the diverse religious situation in different parts of Poland.

${ }^{80}$ M. Cackowska, P. Stańczyk, Katecheza szkolna - między..., op. cit., p. 20. 
Falkevall B., Livsfrågor och relegionskunskap. En belysning av ett centralt begrepp i svensk religionsdidaktik, Stockholm 2010.

Gunnarsson G.G., Is a »Life Question Approach« Appropriate when Religious Education has Become a Part of Social Studies? in: Challenging Life Existential Questions as a Resource for Education, ed. J. Ristiniemi, G. Skeie, K. Sporre. Münster - New York: Waxman, 2018.

Hartman, S.G., \& Petterson S., Livsfrågor och livsåskådning hos barn: några utgångspunkter för en analys av barns livsfrågor och livsåskådning samt en presentation av några delstudier inom området, Stockholm 1980.

Hartman S.G., Children's philosophy of life, Stockholm: Stockholm Institute of Education, 1986.

Hartman S.G., Barns tankar om livet, Stockholm 1986.

Hartman S.G., Hur religionsämnet formades. In: Livstolkning och värdegrund: att undervisa om religion, livsfrågor och etik, Linköping 2000.

Hartman S.G., Livstolkning hos barn och unga. In: Livstolkning och värdegrund: att undervisa om religion, livsfrågor och etik, Linköping 2000.

Hartman S.G., Children Searching for a Philosophy of Life. In: Challenging Life Existential Questions as a Resource for Education, ed. J. Ristiniemi, G. Skeie, K. Sporre, Münster - New York 2018.

Holmqvist Lidh C., Representera och bli representerad: Elever med religiös positionering talar om skolans religionskunskapsundervisning, Karlstad 2016.

Hovde Bråten O.M., World Views in Norwegian RE. In: Challenging Life Existential Questions as a Resource for Education, ed. J. Ristiniemi, G. Skeie, K. Sporre, Münster. New York: Waxman, 2018.

Ipgrave J., Dialogue, Citizenship and Religious Education. In: International Perspectives on Citizenship, Education and Religious Diversity, ed. R. Jackson, London: Routlege Falmer, 2003.

Jackson R., Rethinking Religious Education and Plurality: Issues in Diversity and Pedagogy, London: Routlege Falmer, 2004.

Jackson R., Contextual Religious Education and the Interpretive Approach. "British Journal of Religious Education", 1 (2008).

Jackson R., The development and dissemination of Council of Europe policy on education about religions and non-religious convictions, "Journal of Beliefs and Values", 2 (2014): 133-143.

Kittelmann Flensner K., Religious education in contemporary pluralistic Sweden, Göteborg: University of Gothenburg, 2015. 
Klus-Stańska D., Konstruowanie wiedzy w szkole, Olsztyn: Wydawnictwo Uniwersytetu Warmińsko-Mazurskiego, 2002.

Klus-Stańska D., Mitologia transmisji wiedzy, czyli o konieczności szukania alternatyw dla szkoły, która amputuje rozum, "Problemy Wczesnej Edukacji", 2 (2008): 35-45.

Konferencja Episkopatu Polski, Podstawa programowa katechezy Kościoła katolickiego w Polsce, Kraków: Wydawnictwo WAM, 2010.

Konferencja Episkopatu Polski, Podstawa programowa katechezy Kościoła Katolickiego w Polsce, Częstochowa: Edycja Świętego Pawła, 2018.

Leganger-Krogstad H., Dialogue Among Young Citizens in a Pluralistic Religious Education Classroom. In: International Perspectives on Citizenship, Education and Religious Diversity, ed. R. Jackson, London 2003.

Lgr 62: Läroplan för grundskolan, Stockholm 1962.

Lgr 69: Läroplan för grundskolan. 1, Allmän del, Stockholm 1969.

Lgr 80: Läroplan för grundskolan, Stockholm 1980.

Lipman M., Sharp A.M., Oscanyan F.S., Filozofia w szkole, Warsaw: Wydawnictwo CODN, 1997.

Lpo 94: Kursplaner för grundskolan, Stockholm 1994.

Mąkosa P., Katecheza młodzieży gimnazjalnej w Polsce. Stan aktualny i perspektywy rozwoju, Lublin: Wydawnictwo KUL, 2009.

Mąkosa P., Wspótczesne ujęcia nauczania religii w europejskim szkolnictwie publicznym, "Roczniki pastoralno-katechetyczne", 3 (2011): 123-136.

Marek Z., Edukacja religijna w poszukiwaniu odpowiedzi na egzystencjalne pytania człowieka, "Paedagogia Christiana", 2 (2017): 11-32.

Pajer F., Nauczanie religii w europejskich systemach oświatowych, "Przegląd Powszechny", 6 (1992): 385-296.

Risenfors S., Liberal Muslim, Atheist Hindu and Born-again Christian Identifications in Relation to Religion among Three Upper Secondary Students with Experiences Connected to Migration. In: Challenging Life Existential Questions as a Resource for Education, ed. J. Ristiniemi, G. Skeie, K. Sporre. Münster-New York: Waxmann, 2018.

Sauer R., Religionsunterricht in Europa. In: Ökumenisches Arbeitsbuch Religionspädagogik, ed. H. Noormann, U. Becker, B. Trocholepczy, Stuttgart 2000.

Skeie J., A Culturally conscious religious education, Trondheim 1998. 
Śliwerski B., Czy możliwy jest w szkole dialog?, „Paedagogia Christiana”, 1 (2010): 175-192.

Śnieżyński M., Zarys dydaktyki dialogu, Kraków: Wydawnictwo Naukowe Papieskiej Akademii Teologicznej, 1998.

Sterkens C., Interreligious Learning. The Problem of Interreligious Dialogue in Primary Education, Leiden: Brill, 2001.

Stern E., Kind, Krankheit und Tod, München: Ernst Reinhardt Verlag, 1957.

Szczepska-Pustkowska M., Od filozofii dzieciństwa do dziecięcej filozofii życia. Casus władzy (i demokracji), Kraków: Impuls, 2011.

Tonåringen och livet: undersökning och diskussion kring tonåringen och livsfrågorna, eds. T. Hasselrot, L.O. Lernberg, Stockholm 1980.

Tonåringen och livsfrågorna: elevattityder och undervisningen i livsåskådning och etik på grundskolans högstadium: elevundersökningar och metodiska förslag av en arbetsgrupp inom skolöverstyrelsen, Stockholm 1969.

Weisse W., Difference Without Discrimination: Religious Education as a Field of learning for Social Understanding? in: International Perspectives on Citizenship, Education and Religious Diversity, ed. R. Jackson, London: Routlege Falmer, 2003.

Wright A., Contextual Religious Education and the Actuality of Religions. "British Journal of Religious Education", 1 (2008): 3-12.

Wright A., Religion, Education and Post-modernity, London: Rout. 
